$\sim 530^{\circ} \mathrm{C}$ に常に維持されている. $500^{\circ} \mathrm{C}$ 前後で は分解率が $90 \%$ 以上の能力がある.（図 c )反応 前(1)反応後(2)の各々の Sample をとり Gaschromatography（カラム, クロモソルブ 105, キャ リアーガス; ヘリウム, 温度 $; 40^{\circ} \mathrm{C}$ ) で調べる とまず最初のピークは $\mathrm{N}_{2}$ や $\mathrm{O}_{2}$ が一緒に 1.29 分後に出現し6.19分後に $\mathrm{N}_{2} \mathrm{O}$ のピークがでる. 反応後 (2)の Samysle では $\mathrm{N}_{2} \mathrm{O}$ のピークが完 全に消失していることが，わかる．この分解装 置の能力は $90 \%$ 以上である. 結論として, これ ら余剩排出ガス操置をより完全なものにするに は(1)麻酔医の再認識と技術の向上(2)空調の流速 と換気回数の改善(3)完全なる排出分解装置の設 置が必要であるといえる.

\section{0. 市販エァフィルタの細菌捕集率} 実用通過風速下での測定——

東京医歯大 手術部

○宮前卓之 上田伊佐雄 古橋正吉

エァフィルタは, 種類により, 使用に適した 通過風速が異る.沪材の単位面積当りにすると, 阻塵用フィルタは, $0.20 \mathrm{~m} /$ 秒, 中性能フィル 夕は, $0.05 \sim 0.10 \mathrm{~m} /$ 秒, 高性能フィル夕は, $0.025 \mathrm{~m} /$ 秒程度である.

11種類のエァフィルタを対象に, 供試菌のエ アゾルを上述の速度で通過させ，そのときの細 菌捕集率を私共の実験装置で測定した.

実験方法 : Serratia marcescens $\mathrm{K}_{1}$ の $10^{7}$ 個 $\mathrm{m} l の$ trypticase soy broth を超音波ネブライザ でエァゾル化し，そのエァゾルを試験沪材を通 して Andersen sampler (trypticase soy agar 使用)に吸引儿, 通過した細菌を培養 $\left(28 \sim 30^{\circ} \mathrm{C}\right.$, 24時間）して数え，沪材を雨入せずに同様の操 作を行ったときに得られる菌数を 100 として捕 集率を計算した。

エァゾルの沪材通過速度は, 使用する沪材の 面積を変えることにより調節した。

実験成績：各フィルタについて17 20回測定 をくり返したときの細菌捕集率は下記の通りで あった。

\begin{tabular}{c|c|c} 
Na & フィルタの種類 & 細菌捕集率(\%) \\
\hline (A) & D O P 99.97\%フィルタ & 99.9999 \\
(B) & D O P 99.97\%フィルタ & 99.9994 \\
(C) & D O P 99.97\%フィルタ & 99.9964 \\
(D) & D O P 95\%フィルタ & 99.989 \\
(E) & D O P 75\%フィルタ & 99.88 \\
(F) & N B S 95\%フィルタ & 99.85 \\
(G) & N B S 85\%フィルタ & 99.51 \\
(H) & D O P 63\%フィルタ & 97.2 \\
(I) & N B S 75\%フィルタ & 93.6 \\
(J) & DO P 40\%フィルタ & 83.8 \\
(K) & D O P 20 30\%フィルタ & 54.5 \\
\hline
\end{tabular}

なお，エァゾルの沪材通過速度は，上記No。 亿 よって,

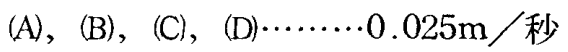
(E), (H),$(J) \cdots \cdots \cdots \cdots \cdots .0 .05 \mathrm{~m} /$ 秒

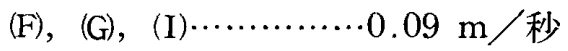
(K)……………………

の条件下で測定した。

\section{1. 新設中央手術室の清潔状稳の推移につい て（II 報）}

愛媛大 中央手術部

○砂田柳子 西森美和子 門田稔熊本良悟 武智 誠広田玲子 矢野正仁 永井勲

愛媛大学中央手術部は, 開院後約 2 年になる が，開院以前から手術部内の清潔状態を調查し， その推移を検討しながら清潔環境改善をめざし てきた。

(研究方法) 手術部内空中浮遊塵埃数は, ダ ストカウンターを用い 0.5 ミクロン以上の塵埃 数を測定し, 空中浮遊細菌数は, アンダーソン サンプラーを使用し，1立方フィートあたりの 細菌数を測定した. 手術部内床壁表面附着細菌 数及び手術部内持ち込々物品表面附着細菌数を スタンプアガーを用いて測定した。

(研究成績) (1)空中浮遊塺埃数は, 開院前に 比べ開院後は著明に減少したが，開院後 7 力月 と 1 年 6 カ月を比較すると, HEPA フィルタ 一手術室では変化はなかったが, 通常空調手術 室では，約 $1 / 2$ に減少した。(2)空中浮遊細菌数は 開院前 $3 \sim 4$ 個であったものが，開院 7 カ月で 